\title{
EFFECT OF DIETARY CATION - ANION DIFFERENCES (DCAD) ON RUMEN FERMENTATION, DIGESTIBILITY AND MILK PRODUCTION IN FRIESIAN DAIRY COWS
}

\author{
Shereen M. El-Mashed ${ }^{1}$; H.M. Metwally ${ }^{2}$; A.M.A. Salama ${ }^{1}$ and H.M.Gado $^{2}$ \\ ${ }^{1}$ Animal Production Research Institute, Ministry of Agriculture, Dokki, Giza, Egypt. \\ ${ }^{2}$ Department of Animal Production, Faculty of Agriculture, Ain Shams University, Cairo, Egypt.
}

\section{SUMMARY}

$\mathrm{T}$ Iwenty Friesian cows were used to study the effect of dietary cation-anion differences on digestibility, rumen fermentation and milk production. Animals were divided into four groups. All groups were fed a basal diet consisting of $30 \mathrm{~kg}$ berseem, $6 \mathrm{~kg}$ concentrate feed mixture (CFM), 6 $\mathrm{kg}$ rice straw $\& 75 \mathrm{~g}$ soya bean meal $(\mathrm{SBM})$ as a carrier for anionic salts/head/day. Anionic salts were used to control DCAD of the ration at the following levels (groups): treatment (1): Control group was fed the basal diet without anionic salts; treatment (2): DCAD was controlled to be $0 \mathrm{mEq} / \mathrm{Kg} \mathrm{DM}$; treatment (3): DCAD was controlled to be negative $150 \mathrm{mEq} / \mathrm{Kg} \mathrm{DM}$; treatment (4): DCAD was controlled to be negative $150 \mathrm{mEq} / \mathrm{Kg} \mathrm{DM}$ by using Anio - Norel (commercial product).

Animals received treatments three weeks before expected calving date and stopped at delivery day.

Results obtained showed that:

1. Rumen $\mathrm{pH}$ was affected by treatment, values were 7.5, 6.9, 6.6 and 7.1 for groups (1, 2,3and 4 respectively).

2. Organic matter digestibility ranged between $59.43 \%$ for group (3) and $57.23 \%$ for group (4).

3. Crude fiber digestibility was not significantly $(\mathrm{P}>0.05)$ affected by treatment.

4. Treated groups showed lower 305 days milk yield when compared with control group $(\mathrm{P}<0.05)$.

5. Treatments didn't affect milk components significantly $(\mathrm{P}>0.05)$ except for milk fat where it was lower for treatment (4) compared with other treatments.

Keywords: DCAD, digestibility, rumen fermentation, milk production and dairy cows.

\section{INTRODUCTION}

Manipulation of dietary cation-anion difference (DCAD) is a procedure commonly used in dairy cattle farms to control milk fever. Dietary cation-anion difference (DCAD) can be used to determine the relationship between strong cations (sodium, potassium, calcium and magnesium) and anions (sulphure and chlorine) and thus predict whether a diet will evoke an acidic or alkaline response when fed to a dairy cow (Stewart, 1983 and Oetzel and Barmore, 1993).

DCAD is expressed as $\mathrm{mEq} / 100 \mathrm{~g} \mathrm{DM}$ or $\mathrm{mEq} / \mathrm{kg}$ DM. Several equations has been suggested to calculate DCAD:

$\left(\mathrm{Na}^{+}+\mathrm{K}^{+}\right)-\left(\mathrm{Cl}^{-}+\mathrm{S}^{-}\right)=\mathrm{mEq} / 100$ gm of DM. (Tucker et al. (1992)

$\left(\mathrm{Na}^{+}+\mathrm{K}^{+}\right)-\left(\mathrm{Cl}^{-}\right)=\mathrm{mEq} / 100 \mathrm{gm}$ of DM... (Mongin, 1981).

The DCAD may also be calculated by using the dietary percent of respective minerals on dry matter basis (DM) with the following equation (Olson, 1991 and West, 1993).

$\mathrm{DCAD}=\{(\mathrm{Na} \% / 0.023)+(\mathrm{K} \% / 0.039)\}-\{(\mathrm{Cl} \% / 0.0355)+(\mathrm{S} \% / 0.016)\} \mathrm{mEq} / 100 \mathrm{~g} \mathrm{DM}$.

Several researcher studied the effect of pre-partum anionic supplementation on feed intake, (DeGroot et al., 2010), Hu and Murphy (2004), Hu et al. (2007), West et al. (1992). They all agreed that DM intake increases as DCAD increases. While Spanghero (2004) reported a decrease in DM intake by animals fed low DCAD diets. Increased DM intake at high DCAD diets might be due to increased rumen PH (Tucker et al., 1988; Sharif et al., 2009; and Sharif et al., 2010) that makes the ruminal environment alkaline, which is pre - requisite for optimum ruminal microbial activity.

DeGroot et al. (2010), mentioned that pre-partum diet had no effect on pre-partum dry matter intake while postpartum dry matter intake and milk yield for cows fed anionic diets pre-partum were greater compared with those fed the control diet. 


\section{Elmashed et al.}

Shahazad et al. (2011), used four iso-nitrogenous and iso-caloric diets having different DCAD (-22,$11,+11$ and $+22 \mathrm{mEq} / 100 \mathrm{~g} \mathrm{DM}$ ) to study the effect of acidifying diet on DM intake and digestibility in Buffaloes. They concluded that a linear increase in nutrient intake was recorded with increase in the DCAD level. On the other hand Buffaloes fed with high anionic diets had higher nutrients digestibility than those fed with high cation diets. Influence of varying DCAD diets on nutrients digestibility was investigated by Delaquis and Block (1995 a \& b) and Tucker et al. (1991). They used different positive DCAD values and found no significant effect on ADF and NDF digestibility.

Ganjkhanlou et al. (2010) conducted a study to evaluate the effect of three diets with different (DCAD) values $(+13,0$ and $-13 \mathrm{mEq} / 100 \mathrm{~g} \mathrm{DM})$ on milk production in Holstein Cows. Their results indicated that production of milk and $3.5 \%$ fat corrected milk were increased with decreasing DCAD. On the other hand milk composition was not affected by DCAD.

The main objective of this study was to investigate the effect of pre-parturient DCAD levels on rumen fermentation, digestion and milk production of lactating Frisian cows.

\section{MATERIALS AND METHODS}

The field experiment of this study was conducted from April 2014 to August 2015 (treatments started three weeks before expected delivery date and ended on day of parturition, while milk parameters were recorded until the end of lactation season) at El Karada experimental station, Kafr El-Sheikh governorate, which belongs to the Animal Research Institute, Ministry of Agriculture.

Twenty Late pregnant Friesian cows ( 3 to 4 weeks before calving) were used through the experiment. Animals were divided according to the parity to four groups, five cows each. Animals were housed in four separate open areas provided with water sinks and shades. Animals were tied at feeding time to be fed individually berseem, concentrate feed mixture and rice straw according to NRC (2001). Ingredients of concentrate feed mixture are shown in Table (1) and chemical composition of feedstuffs are shown in Table (2).

All animals were fed on the basal diet and the following additives:

Treatment (1): Control group received soybean meal without anionic salts (soybean meal was used as a carrier for anionic salts which added to other groups).

Treatment (2): Received (150 gm) anionic salt to achieve DCAD equal zero $\mathrm{mEq} / \mathrm{Kg}$ DM. composition of anionic salts are shown in Table (3).

Treatment (3): Received (350 gm) Soybean meal + anionic Salt to achieve DCAD equal (-150) $\mathrm{mEq} / \mathrm{Kg}$ DM.

Treatment (4): Received (350 gm) Anio-Norel compound to achieve DCAD equal (-150) $\mathrm{mEq} / \mathrm{Kg} \mathrm{DM}$. composition of Anio-Norel is presented in Table (4).

DCAD was calculated according to the following equation:

$\mathrm{DCAD} \mathrm{mEq} / \mathrm{Kg} \mathrm{DM}=(\mathrm{Na}+\mathrm{K})-(\mathrm{Cl}+\mathrm{S})$.

Representative samples were taken from all feed stuffs before, during, and after experimental period. The three samples of each feedstuff were kept frozen and composited till analysis. Rumen samples were collected using stomach tube once after one week of treatments three hours after feeding. Samples were filtered through four layers of cheesecloth's and $\mathrm{pH}$ was measures using portable $\mathrm{pH}$ meter. Two drops of formaldehyde were added to the sample in ordered to stop microbial growth then samples were kept frozen. Fecal samples were grabbed from the rectum of experimental animals three executive days one week after treatment beginning. Samples were frozen. The three samples of each animal were composited before analysis. Feed and fecal samples were analyzed for proximate analysis according to AOAC (2006) and fiber fractions were determined according to Goering and Van Soest (1970) modified by Van Soest $e t$ al., (1991). Digestibility was determined using two internal markers Acid Detergent Lignin (ADL) and Acid Insoluble Ash (AIA).

Milk production was recorded twice daily. Fifty milliliters of milk were obtained weekly for each animal up to the third month of milking then monthly samples were collected up to the end of milking season. Samples were send fresh to be analyzed for fat, protein, total solids and solids nonfat and lactose using Milkoscan device (Foss Electric, Denmark) belongs to International Center for Animal Husbandry in kafr El-Sheihk, Sakha.

All the obtained data were statistically analyzed using the General Linear Model Program of SAS (2000). Statistical models were as follow:

For digestion: $Y_{\mathrm{ijk}}=\mu+t_{\mathrm{i}}+\mathrm{m}_{\mathrm{j}}+\mathrm{t}_{\mathrm{i}} \mathrm{m}_{\mathrm{j}}+\mathrm{e}_{\mathrm{ijk}}$ 
Were $\mathrm{Y}_{\mathrm{ijk}}$, is the dependent valuable; $\mu$ is the overall mean. $\mathrm{t}_{\mathrm{i}}$; is the effect of treatment; $\mathrm{m}_{\mathrm{j}}$, is the effect of marker; $\mathrm{t}_{\mathrm{i}} \mathrm{m}_{\mathrm{j}}$, is the effect of interaction between treatment and marker; $\mathrm{e}_{\mathrm{ijk}}$, is the residual error.

For milk components: $Y_{i j k}=\mu+t_{i}+w_{j}+t_{i} W_{j}+e_{i j k}$

Were $Y_{\mathrm{ijk}}$, is the dependent valuable; $\mu$; is the overall mean. $t_{\mathrm{i}}$; is the effect of treatment; $w_{j}$, is the effect of week of lactation; $\mathrm{t}_{\mathrm{i}} \mathrm{W}_{\mathrm{j}}$, is the effect of interaction between treatment and week of lactation; $\mathrm{e}_{\mathrm{ijk}}$, is the residual error.

For milk production: $\mathrm{Y}_{\mathrm{ijk}}=\mu+\mathrm{t}_{\mathrm{i}}+\mathrm{m}_{\mathrm{j}}+\mathrm{t}_{\mathrm{i}} \mathrm{m}_{\mathrm{j}}+\mathrm{n}_{\mathrm{k}}+\mathrm{e}_{\mathrm{ijk} \mathrm{l}}$

Were $Y_{\mathrm{ijk}}$, is the dependent valuable; $\mu$ is the overall mean. $\mathrm{t}_{\mathrm{i}}$; is the effect of treatment; $\mathrm{m}_{\mathrm{j}}$, is the effect of milking time (morning and evening) ; $\mathrm{t}_{\mathrm{i}} \mathrm{m}_{\mathrm{j}}$, is the effect of interaction between treatment and milking time; $\mathrm{n}_{\mathrm{k}}$ is the effect of lactation month $\mathrm{e}_{\mathrm{ijkl}}$, is the residual error.

Duncan's new multiple range test (Duncan, 1955) was used to determine the significant differences among treatments.

\section{RESULTS AND DISCUSSIONS}

Data in Table (5) showed, a trend of lowered dry matter intake with more anionic diets (i.e. a decrease in DCAD). These findings are similar to those obtained by Oetzel and Barmore(1993) who observed an increasing trend in dry matter intake as DCAD was increased from -109 to $+313 \mathrm{mEq} / \mathrm{kg}$ DM. In the present study DCAD decreased from +90 for control group to $-150 \mathrm{mEq} / \mathrm{kg}$ DM in treatments (3\&4). However treatment (4) (Anio-Norel group) didn't have this negative effect on dry matter intake. This may be explained by buffering effect of materials included in its composition which kept the rumen PH close to control group. Explanation of the effect of rumen PH on dry matter intake was cleared by Tucker et al. (1988); Sharif et al. (2009) and Sharif et al. (2010). They mentioned that the ruminal environment alkalinity is pre-requisite for optimum ruminal microbial activity. Goff et al. (1988) and Shahzad et al. $(2008 \mathrm{a}, \mathrm{b})$ stated that explanation of dry matter intake decreased might be the unpalatability of anionic salts used to reduce the DCAD level. Another possible explanation might be that low DCAD induces slight metabolic acidosis, which reduces dry matter intake (Block, 1994).

Rumen PH values, rumen VFA $m M$ and rumen ammonia $\mathrm{mg} / 100 \mathrm{ml}$ are shown in Table (6). Rumen PH tended to be lower with treatments (2) and (3) where anionic salts were added to the diet, compared with control group. However when Anio-Norel was used the PH values increased. To be similar to treatment to $(p>0.05)$ but still significantly less than control and more than treatment $(3)(p<0.05)$. This can be explained by buffer effect of yeast and magnesium oxide included in Anio- Norel mixture. Total volatile fatty acid concentrations were increased with treatments (2) and (3) when compared with control and Anio-Norel groups. Ammonia concentrations were lower with treatments (2) and (3) (14.8mg/100ml) while they were higher for control and Anio- Norel groups $(16.4,16.3 \mathrm{mg} / 100 \mathrm{ml})$ respectively. In contrast with the present results Apper-Bossard et al. (2010) stated that increasing DCAD did not affect mean ruminal $\mathrm{pH}$, neither total VFA concentration nor molar proportion of VFA and rumen ammonia concentration, however levels of DCAD of their studies ranged between 0,150 , or $300 \mathrm{mEq} / \mathrm{kg}$ of DM while the present study used DCAD levels of $+90,0,-150 \mathrm{mEq} / \mathrm{kg}$ of DM. Moreover they used milking cows rather than dry cows used during the present study. A localized rumen buffering effect could not be excluded and could be linked with a higher amount of $\mathrm{HCO} 3$ recycled into the rumen. (Apper-Bossard $e t$ al., 2010).

Analysis of variance showed that mean effect (treatments) affected significantly $(\mathrm{p}<0.05)$ hemicellulose, cellulose and organic matter digestibility. While there was no significant effect of treatments on crude protein, fiber, ADF, NDF and dry matter digestibility. Data in Table (7) indicated that treatment (4) (Anio-Norel) decreased significantly $(\mathrm{p}<0.05)$ the digestibility of cellulose. Hemicellulose digestion was decreased by treatment (2). Organic matter digestibility was higher significantly for treatments (2 and 3) and lower for treatments (1 and 4). Influence of varying DCAD diets $(481,327 \mathrm{mEq} / \mathrm{kg}$ DM) on nutrients digestibility was investigated by Delaquis and Block (1995a). They reported that DCAD had nonsignificant effect on ADF and NDF digestibilities in dry cows.

A comparison between apparent digestibility of different nutrients calculated by two different internal markers are presented in Table (8). When Acid insoluble Ash (AIA) and Acid Detergent lignin (ADL) were used to calculate the digestibility of nutrients, values obtained were in general higher significantly $(\mathrm{p}<0.05)$ forADL when compared with AIA. This is true for all nutrients except for crude protein where differences were not significant. Juvenal Kanani et al. (2014) concluded that acid-detergent insoluble ash appear to be appropriate internal markers for predicting fecal output and dry matter digestibility by cattle fed Bermuda grass hay of varying quality. They recommended that such internal markers will facilitate 


\section{Elmashed et al.}

larger studies involving greater numbers of animals and forages to determine the digestibility by applying the marker ratio technique. These studies can then be used to develop more accurate equations to predict energy values of forages based on the relationship of dietary components to digestibility across a wide range of forages

Significant interaction between markers and treatments was only observed with organic matter digestibility (Table 9). Although, in general, values with (ADL) were higher than (AIA), differences were not the same. Differences between organic matter digestibility obtained by the two markers were the highest in control group 33.79 and the lowest in group (2) 29.98. Fluctuations of these differences may be explained by minerals contained in different treatments. In their studies, Juvenal Kanani et al. (2014) reported an interaction between marker and diet at significance level of $(\mathrm{P}<0.06)$ while the present study find the interaction significant at $(p<0.05)$. The interaction may be explained by different sources of minerals used to manipulate DCAD level.

Total milk yield ( $\mathrm{Kg} / \mathrm{season})$, milking days and corrected milk yield for 305 days are shown in Table (10) and diagram (1). Data indicated that total milk through the whole season was the highest in group (2) and the lowest in group (3). These may be due to the length of milking days which were 191.2 milk days in group (3) and 341.7 milk days for group (2). When milk production was corrected for 305 days the control group showed the highest values $3421.62 \mathrm{Kg}$ followed by group (2) $3191.91 \mathrm{Kg}$ and Anio- Norel group $3181.29 \mathrm{Kg}$ while group (3) stayed lowest to $612.65 \mathrm{Kg}$.

Results of Table (11) indicated that milk yield was lowered by treatment (3) compared with the other groups which had statistical similar values. These values of milk production may reflect the dry matter intake through the transitional period. In contrast Ganjkhanlou et al. (2010) reported that production of milk and 3.5\% fat corrected milk were increased with decreasing DCAD. These conflict of results may be explained by variation in length of experimental periods, cows body weight $(620 \mathrm{Kg}$ Vs 520 in the present study) and season of lactation. In their study animals were fed experimental diets for $60 \pm 5$ days comparing with last three weeks before delivery (21 days) in the present study. However Tucker et al., (1988) and West et al., (1991) observed increased milk yield in lactating cows as DCAD level increased from -10 to $+31 \mathrm{mEq} / 100 \mathrm{~g} \mathrm{DM}$. which agree with the finding of the present study.

Morning and evening milk yield through 30 days were presented in Table (12). Morning milk yield was significantly higher than evening.

Monthly milk production decreased with increasing lactation month after parturition (Table 14). The relationship tended to be linear in treatments $(1 \& 2)$ while it was more quadratic in treatment (4) revealing more persistence for Anio-Norel group.

Data in Table (15) present the effect of treatments on milk components throughout the first 16 weeks of lactation. Results indicated that anionic salts didn't affect milk protein, lactose, total solid (TS) and solid not fat (SNF). However milk fat was decreased in treatment (4) when compared with other treatments. Interaction between weeks and treatments were not significant for all milk components. On the other hand protein was the only components affected significantly by weeks after parturition (Table 16). The highest protein content was obtained through the first week and the lowest was through the second week.

\section{CONCLUSION}

Anionic salts may be added to the diets through transition period of the dairy cows to decrease the DCAD in order to prevent post-partum clinical or sub clinical milk fever. However, anionic salts may cause a lower rumen $\mathrm{PH}$ which may affect some nutrients digestibility and consequently low milk production. Therefore, it is recommended to use a buffering material such as sodium bicarbonate or yeast with anionic salts to ensure alkalinity in the rumen.

\section{REFERENCES}

AOAC. (2006). Official Methods of analysis of AOAC international, $18^{\text {th }}$ ed. AOAC international, Arlington, VA, USA.

Apper-Bossard, E.; P. Faverdin; F.Meschy and J.L. Peyraud (2010). Effects of dietary cation-anion difference on ruminal metabolism and blood acid-base regulation in dairy cows receiving 2 contrasting levels of concentrate in diets. J Dairy Sci., 93(9):4196-210. 
Block, E. (1994).Manipulation of dietary cation-anion difference on nationally related production diseases, productivity, and metabolic response of dairy cows. J. Dairy Sci., 77:1437-1450.

DeGroot, M.A.; E. Block and P.D. French (2010). Effect of pre-partum anionic supplementation on periparturient feed intake, health, and milk production. J. Dairy Sci., 93:5268 - 5279.

Delaquis, A.M. and E. Block (1995a). Acid- base status, renal function, and macromineral metabolism of dry cows fed diets differing in cation-anion difference. J. Dairy Sci., 78:604-619.

Delaquis, A.M.and E. Block (1995b). The effects of changing ration ingredients on acid- base status, renal function and macromineral metabolism. J. Dairy Sci., 78:2024-2039.

Duncan, D.B. (1955). Multiple range and multiple F. test. Biometric, 11:142.

Ganjkhanlou, M.; A. Nikkhah and A. Zali (2010). Effect of dietary cation-anion balance on milk production and blood minerals of Holstein cows during the last two months of pregnancy. African Journal of Biotechnology, 9(36):5983-5988.

Goering, H.K. and P.J. Van Soest (1970). Forage fiber analyses (apparatus, reagents, procedures and some applications). Agric. Handbook 379 ARS, USDA, Washington DC, USA.

Goff, J.P.;R.L.Horst;D.C.Beitz andE.T.Littledike (1988). Use of 24-F-1, 25-dihydroxyvitamin D3 to prevent parturient paresis in dairy cows. J.Dairy Sci., 71: 1211-1219.

Hu, W.; Jr. L.Kung andM.R.Murphy (2007). Relationships between dry matter intake and acid - base status of lactating dairy cows as manipulated by dietary cation-anion difference.Anim, Feed Sci. Technol., 136:216-225.

Hu, W. and M.R. Murphy (2004). Dietary Cation-Anion Difference Effects on performance and acid - base Status of lactating Dairy Cows. A Meta- analysis. J. Dairy Sci., 87:2222-2229.

Juvenal, K.;P. Dirk; Kenneth P Coffey, Elizabeth B.Kegley, Charles P. West, Shane Gadberry, John Jennings, Ashley N. Young and Robert T.Rhein (2014).Comparison of acid-detergent lignin, alkalineperoxide lignin, and acid-detergent insoluble ash as internal markers for predicting fecal output and digestibility by cattle offered bermudagrass hays of varying nutrient composition. Journal of Animal Science and Biotechnology, 5:7

Mongin, P. (1981). Recent advances in dietary cation anion balance. Applications in poultry. Proc. Nutr. Soc., 40:285-294.

NRC (2001). Nutrient Requirements of Dairy cattle $7^{\text {th }}$ ed. Natl. Research Council, Acad. Press, Washington, DC. USA.

Oetzel, G.R. and J.A. Barmore (1993). Palatibility of anionic salts fed in a concentrate mix. J. Dairy Sci., 76:1617.

Olson, J.D. (1991). Relationship of nutrition to abomasal displacement and parturient paresis. Bov. Prac., 26:88-91.

SAS (2000). User's Guide: Statistical, version 7- 12 edition. SAS inst. Inc., Cary. NC.

Shahzad, M.A.; M. Sarwar and N. Nisa (2008a). Influence of altering dietary cation anion difference on milk yield and its composition of early lactating NILI Ravi buffaloes in summer. Lives Sci., 113: 133143.

Shahzad, M.A.; M.Sarwar and N.Nisa (2008b). Influence of varying dietary cation anion difference on serum minerals, mineral balance and hypocalcemia in NILI Ravi buffaloes in summer. Lives Sci., 113: 52-61.

Shahazad M.A.; M. Sherif; M. Nisa; M. Sarwar; M.F. Khalid and H.A. Saddiqi (2011). Changing certain dietary cationic and anionic minerals: Impact on blood chemistery, milk fever and other udder edema in buffaloes during winter. African Journal of Biotechnology, 10(62):13651-13663.

Sharif, M.; M.A. Shahzad; M. Nisan and M. Sarwar (2010). Influence of varying levels of dietary cation anion difference on nutrient intake, ruminal characteristics, nitrogen metabolism and in situ digestion kinetics in Nili Ravi buffalo Bulls. Anim. Sci. J. doi: 10.1111/j. 1740-092902010.00780.X

Sharif, M.; M.A. Shahzad; M. Nisan and M. Sarwar (2009). Nutrients intake and ovarian profile as affected by cationic anionic diets in Nili Ravi buffaloes in winter. The $6^{\text {th }}$ Asian Buffalo Congress.University of Vetrinary and Animal Sciences, Lahore, Pakistan.

Spanghero, M. (2004). Prediction of blood and urinary pH in non- lactating dairy cows fed anionic diets. Anim. Feed Sci. Technol., 116:83-92.

Stewart, P.A. (1983). Modern Quantitative acid - base chemistry .Can. J. Physiol. Pharmacol., 61:1444.

Tucker, W.B.; G.A. Harrison and R.W. Henken (1988). Influence of dietary cation - anion balance on milk, blood, urine, and rumen fluid in lactating dairy cattle. J. Dairy Sci., 71:346-352.

Tucker, W.B.;J.F. Hogue; D.F. Waterman; T.S. Swenson; B.Z. Xin; R.W. Hemken; J.A. Jackson; G.D. Adams andL.J. Spicer (1992). Sulfure should be included when calculating the dietary cation - 
anion balance of diets for lactating dairy cows. Anim. Sci. Res Rep Oklahoma Res., Stat Oklahoma City, OK, PP141- 150.

Tucker, W.B.; B.Z. Xin and R.W. Henken (1991). Influence of calcium chloride on systemic acidbase status and calcium metabolism in dairy heifers. J. Dairy Sci., 74:1401-1409.

Van Soest, P.J.; J.B. Robertson and B.A. Lewis (1991).Methods for dietary fiber, neutral detergent fiber and nonstarch polysaccharides in relation to animal nutrition. J. Dairy Sci., 74:3583-3597.

West, J.W.; B.G. Mullinix and T.G. Sandifer (1991). Changing dietary electrolyte balance for dairy cows in cool and hot environments. J. Dairy Sci., 74:1662-1671.

West, J.W.; K.D. Haydon; B.G. Mullinix and T.G. Sandifer (1992). Dietary cation- anion balance and cation source effects on production and acid-base status of heat - stressed cows. J. Dairy Sci., 75:27762786.

West, J.W. (1993). Cation-anion balance. Its role in lactating cow nutrition. Feedstuffs, 10:14-15. 
Table (1). Ingredients of the experimental concentrate feed mixture.

\begin{tabular}{lc}
\hline Ingredients & $\%$ \\
\hline Cotton seed meal & 38 \\
Yellow corn & 32 \\
Wheat Bran & 24 \\
Molasses & 3 \\
Lime stone & 2 \\
Sodium Chloride & 1 \\
\hline
\end{tabular}

Table (2). Chemical composition of feedstuffs.

\begin{tabular}{ccccccccccccc}
\hline Sample & DM\% & NDF & ADF & ADL & Hemi & Cellulose & protein & Ash & fiber & $0 . \mathrm{M}$ & P & Ca \\
\hline CFM & 90 & 30.1 & 14.6 & 3.2 & 15.5 & 11.4 & 12.3 & 13.8 & 37.2 & 86.24 & 0.2 & 0.02 \\
Straw & 82 & 70.1 & 42.3 & 19 & 27.8 & 23.5 & 2.63 & 16.8 & 51.1 & 83.25 & 0.1 & 0.01 \\
Berseem & 19 & 54.4 & 37.4 & 5.6 & 17 & 31.9 & 18.6 & 14.7 & 39.2 & 85.26 & 0.2 & 0.01 \\
\hline
\end{tabular}

Table (3). Anionic salt composition.

\begin{tabular}{lc}
\hline Components & \\
\hline Magnesium sulfate, g & 100 \\
Ammonium sulfate, g & 150 \\
Ammonium chloride, g & 250 \\
Soybean meal (carrier), g & 500 \\
Total, g & 1000 \\
\hline
\end{tabular}

Table (4). Anio-Norel composition.

\begin{tabular}{lc}
\hline Items & Anio-Norel \\
\hline Magnesium sulfate, g & 100 \\
Ammonium sulfate, g & 150 \\
Ammonium chloride, g & 250 \\
Molasses flavor, g & 0.1 \\
Biomet zinc $(15 \%), \mathrm{g}^{*}$ & 7.5 \\
Actisaf, g** & 10 \\
Magnesium oxide , g & 50 \\
Soybean meal (carrier), g & 449.9 \\
Total, g & 1000 \\
\hline
\end{tabular}

$*=$ Chelated Zinc $; *=$ Live Yeast

Table (5). Feed intake.

\begin{tabular}{lcccc}
\hline \multirow{2}{*}{ Items } & \multicolumn{4}{c}{ Treatments } \\
\cline { 2 - 5 } & 1 & 2 & 3 & 4 \\
\hline DMI, Kg/ head / day & 16.02 & 15.5 & 15.3 & 15.95 \\
TDNI , Kg / head / day & 12.5 & 12.2 & 12.4 & 12.5 \\
CPI , g / head / day & 1.853 & 1.751 & 1.770 & 1.844 \\
\hline
\end{tabular}


Table (6). Rumen Parameters.

\begin{tabular}{lccccc}
\hline Items & \multicolumn{3}{c}{ Treatments } & \multirow{2}{*}{ \pm SE } \\
\cline { 2 - 5 } & 1 & 2 & 3 & 4 & \\
\hline PH & $7.5^{\mathrm{a}}$ & $6.9^{\mathrm{b}}$ & $6.6^{\mathrm{c}}$ & $7.1^{\mathrm{b}}$ & \pm 0.21 \\
VFA (mM) & $62^{\mathrm{b}}$ & $65^{\mathrm{a}}$ & $64^{\mathrm{a}}$ & $61^{\mathrm{b}}$ & \pm 2.10 \\
Ammonia(mg/100ml) & $16.4^{\mathrm{a}}$ & $14.8^{\mathrm{b}}$ & $14.8^{\mathrm{b}}$ & $16.3^{\mathrm{a}}$ & \pm 1.20 \\
\hline
\end{tabular}

$a, b$ : means with different letters differ significantly. $(P<0.05)$.

Table (7). Effect of treatments on nutrients digestibility.

\begin{tabular}{lcccccccc}
\hline Treatments & CP & Fiber & ADF & NDF & Hemi & Cellu & OM & DM \\
\hline 1 & 80.51 & 61.50 & 70.31 & 65.66 & $85.73^{\mathrm{a}}$ & $65.11^{\mathrm{a}}$ & $57.37^{\mathrm{b}}$ & 65.75 \\
2 & 83.31 & 65.16 & 68.74 & 63.28 & $82.78^{\mathrm{b}}$ & $59.90^{\mathrm{ab}}$ & $58.87^{\mathrm{a}}$ & 66.19 \\
3 & 84.57 & 64.49 & 68.75 & 62.70 & $85.48^{\mathrm{a}}$ & $58.55^{\mathrm{ab}}$ & $59.43^{\mathrm{a}}$ & 66.10 \\
4 & 88.12 & 62.69 & 69.74 & 63.06 & $87.29^{\mathrm{a}}$ & $57.74^{\mathrm{b}}$ & $57.23^{\mathrm{b}}$ & 66.28 \\
S.E & \pm 4.126 & \pm 4.20 & \pm 0.707 & \pm 0.954 & \pm 0.791 & \pm 1.495 & \pm 0.370 & \pm 0.594 \\
\hline
\end{tabular}

$a, b$ : means with different letters differ significantly. $(P<0.05)$.

Table (8). Comparison between ADL and AIA as digestibility markers.

\begin{tabular}{lcccccccc}
\hline Items & CP & Fiber & ADF & NDF & Hemi & Cellu & O.M. & D.M. \\
\hline ADL & 86.34 & $69.31^{\mathrm{a}}$ & $75.19^{\mathrm{a}}$ & $70.41^{\mathrm{a}}$ & $88.26^{\mathrm{a}}$ & $67.10^{\mathrm{a}}$ & $74.04^{\mathrm{a}}$ & $72.38^{\mathrm{a}}$ \\
AIA & 81.91 & $57.60^{\mathrm{b}}$ & $63.59^{\mathrm{b}}$ & $56.94^{\mathrm{b}}$ & $82.38^{\mathrm{b}}$ & $52.56^{\mathrm{b}}$ & $42.41^{\mathrm{b}}$ & $59.78^{\mathrm{b}}$ \\
S.E & \pm 2.917 & \pm 2.972 & \pm 0.500 & \pm 0.674 & \pm 0.559 & \pm 1.057 & \pm 0.266 & \pm 0.420 \\
\hline
\end{tabular}

$a, b M e a n s$ with different letters differ significantly. $(P<0.05)$.

$A D L=$ Acid detergent lignin $; A I A=$ Acid Insoluble Ash .

Table (9). Effect of interaction between markers and treatments on organic matter digestibility.

\begin{tabular}{|c|c|c|c|c|c|c|c|c|c|}
\hline \multirow{2}{*}{$\begin{array}{l}\text { Treatments } \\
\text { Marker }\end{array}$} & \multicolumn{2}{|c|}{1} & \multicolumn{2}{|c|}{2} & \multicolumn{2}{|c|}{3} & \multicolumn{2}{|c|}{4} & \multirow{2}{*}{ S.E } \\
\hline & A & $\mathrm{L}$ & $\mathrm{A}$ & $\mathrm{L}$ & A & $\mathrm{L}$ & A & $\mathrm{L}$ & \\
\hline Mean & $40.47^{\mathrm{f}}$ & $74.26^{\mathrm{a}}$ & $43.19^{\mathrm{d}}$ & $74.55^{\mathrm{a}}$ & $44.44^{\mathrm{c}}$ & $74.42^{\mathrm{a}}$ & $41.53^{\mathrm{e}}$ & $72.93^{b}$ & \pm 0.532 \\
\hline \multicolumn{10}{|c|}{$\begin{array}{l}a, b, c, d, e, f: \text { means with different letters differ significantly. }(P<0.05) \text {. } \\
A=A I A ; L=A D L .\end{array}$} \\
\hline \multicolumn{10}{|c|}{ Table (10). Effect of treatments on milk production. } \\
\hline Treatments & & & otal milk & & $\mathrm{mil}$ & days & & Ave. in & \\
\hline 1 & & & 3476.40 & & & 60 & & 3421.6 & \\
\hline 2 & & & 3575.95 & & & .75 & & 3191.9 & \\
\hline 3 & & & 1810.22 & & & .20 & & 2612.7 & \\
\hline 4 & & & 3405.45 & & & & & 3181.2 & \\
\hline
\end{tabular}

Table (11). Effect of treatment on average monthly milk yield as an average of two milking a day.

\begin{tabular}{lcccc}
\hline Treatments & 1 & 2 & 3 & 4 \\
\hline Means. & $155.420^{\mathrm{a}}$ & $153.503^{\mathrm{a}}$ & $120.494^{\mathrm{b}}$ & $148.884^{\mathrm{a}}$ \\
S.E. & \pm 4.284 & \pm 4.697 & \pm 5.424 & \pm 4.201 \\
\hline
\end{tabular}

$a, b$ : means with different letters differ significantly. $(P<0.05)$.

Values in the table were calculated according to the following equation:

(Daily milk $/ 2 * 30$ ) for each animal through 11 months and monthly averages for each group are presented in each cell in the table 
Table (12). Effect of milking time (morning / evening).

\begin{tabular}{cccc}
\hline Time & Morning & evening & S.E. \\
\hline means & $159.022^{\mathrm{a}}$ & $134.559^{\mathrm{b}}$ & \pm 3.306 \\
\hline
\end{tabular}

$a, b:$ means with different letters differ significantly. $(P<0.05)$.

Table (13). Effect of lactation months on milk yield (average of 2 milking a day).

\begin{tabular}{lcc}
\hline Month & mean & S.E. \\
\hline 1 & $193.47^{\mathrm{a}}$ & \pm 7.572 \\
2 & $185.32^{\mathrm{ab}}$ & \pm 7.572 \\
3 & $179.48^{\mathrm{ab}}$ & \pm 7.572 \\
4 & $168.88^{\mathrm{bc}}$ & \pm 7.572 \\
5 & $153.31^{\mathrm{cd}}$ & \pm 7.572 \\
6 & $148.14^{\mathrm{cde}}$ & \pm 7.572 \\
7 & $142.94^{\mathrm{de}}$ & \pm 7.572 \\
8 & $128.04^{\mathrm{fe}}$ & \pm 7.572 \\
9 & $116.53^{\mathrm{f}}$ & \pm 7.572 \\
10 & $110.49^{\mathrm{f}}$ & \pm 7.801 \\
11 & $82.16^{\mathrm{g}}$ & \pm 7.801 \\
\hline
\end{tabular}

$a, b, \ldots \ldots$, .: means with different letters differ significantly. $(P<0.05)$.

Table (14). Linear \& Quadratic relationship of milk production with lactation month.

\begin{tabular}{lcccc}
\hline P values & T1 & T2 & T3 & T4 \\
\hline Significance of linearity & 0.0382 & 0.0005 & 0.2142 & 0.0294 \\
Significance of quadratic & 0.7387 & 0.0047 & 0.2033 & 0.0002 \\
\hline
\end{tabular}

Table (15). Effect of treatments on milk composition:

\begin{tabular}{lccccc}
\hline Treatment & Fat & Protein & Lactose & T.S. & SNF \\
\hline 1 & $3.013^{\mathrm{a}} \pm 0.137$ & $2.12 \pm 0.052$ & $4.23 \pm 0.065$ & $10.13 \pm 0.176$ & $7.12 \pm 0.105$ \\
2 & $2.913^{\mathrm{a}} \pm 0.126$ & $2.22 \pm 0.048$ & $4.45 \pm 0.060$ & $10.29 \pm 0.163$ & $7.38 \pm 0.097$ \\
3 & $2.972^{\mathrm{a}} \pm 0.161$ & $2.17 \pm 0.061$ & $4.32 \pm 0.077$ & $10.11 \pm 0.207$ & $7.19 \pm 0.124$ \\
4 & $2.505^{\mathrm{b}} \pm 0.131$ & $2.22 \pm 0.050$ & $4.37 \pm 0.063$ & $9.80 \pm 0.169$ & $7.29 \pm 0.101$ \\
\hline \multicolumn{2}{l}{ a,b: means with different letters differ significantly. $(\mathrm{P}<0.05)}$.
\end{tabular}


Table (16). Effect of week on milk protein.

\begin{tabular}{lcc}
\hline Week & Mean & S.E. \\
\hline 1 & $2.376^{\mathrm{abc}}$ & \pm 0.0912 \\
2 & $1.871^{\mathrm{g}}$ & \pm 0.0912 \\
3 & $1.924^{\mathrm{fg}}$ & \pm 0.0912 \\
4 & $2.023^{\mathrm{defg}}$ & \pm 0.0912 \\
5 & $2.093^{\mathrm{cdefg}}$ & \pm 0.0912 \\
6 & $1.987^{\mathrm{efg}}$ & \pm 0.0912 \\
7 & $1.979^{\mathrm{efg}}$ & \pm 0.0912 \\
8 & $2.177^{\mathrm{bcdef}}$ & \pm 0.0944 \\
9 & $2.308^{\mathrm{abcd}}$ & \pm 0.0944 \\
10 & $2.308^{\mathrm{abcde}}$ & \pm 0.0944 \\
11 & $2.310^{\mathrm{abc}}$ & \pm 0.1022 \\
12 & $2.268^{\mathrm{abcde}}$ & \pm 0.1022 \\
13 & $2.500^{\mathrm{ab}}$ & \pm 0.1176 \\
14 & $2.513^{\mathrm{ab}}$ & \pm 0.1176 \\
15 & $2.672^{\mathrm{a}}$ & \pm 0.1310 \\
\hline
\end{tabular}

$a, b \ldots . . . g$ : means with different letters differ significantly. $(P<0.05)$.

Fig. (1). Effect of treatments on milk production.

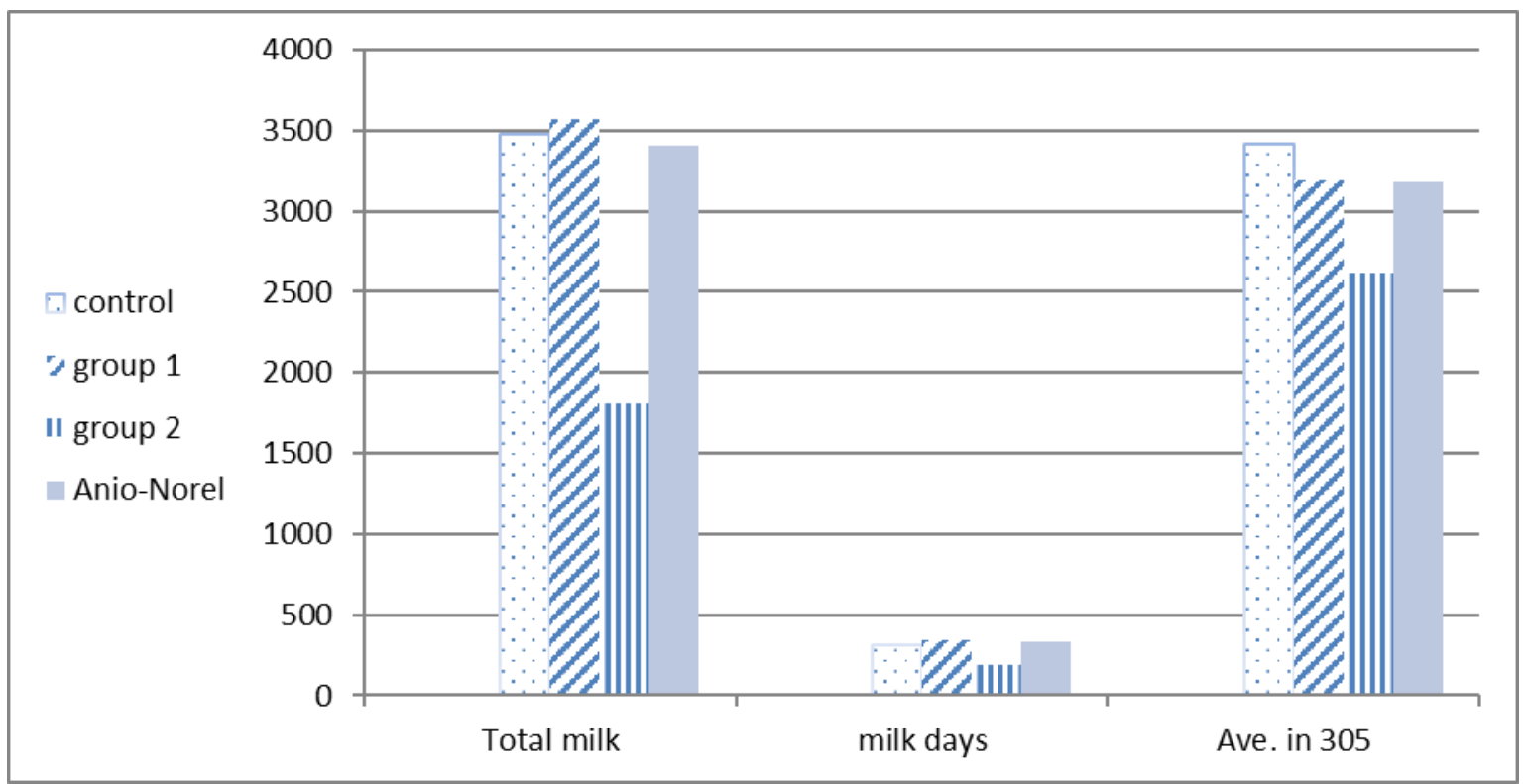


Fig. (2). Effect of lactation month and treatment on milk yield.

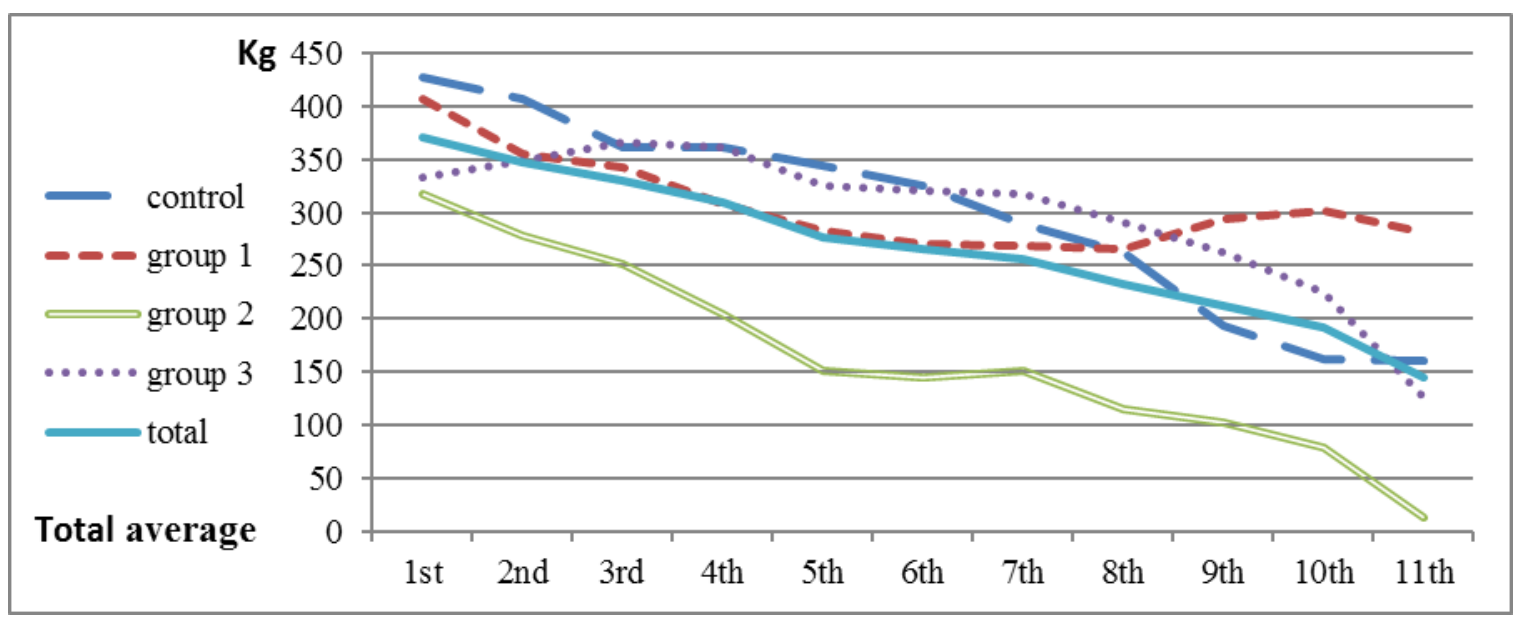

تأثير التوازن الانيونى_ الكاتيونى للعلائق على تخمرات الكرش والهضم وإنتاج الألبان في أبقار الفريزيان

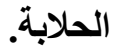

\author{
شيرين محمد المثد1 , حمدي موسى متولي² , أحمد محمد أحمد سلامة1 , هانئ محمود جادو2

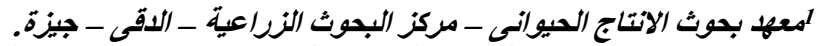

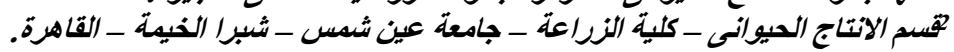

تستخدم إضافات الأملاح الأنيونية للعلائق كإجراء وقائي في أخر مراحل الحمل لتجنب الإصابة بحمى اللبن بعد الو لادة وهو إجر اء أصبح روتينيا في معظم مز ارع الألبان. أستخدمت الَّراسة عشرين بقرة فريزيان حلابة لدراسة تأثير التوازنبين الكاتيونات والانيونات في العلائق على معدلات الهضم وتخمر ات الكرش و إنتاج اللبن. قسمت الحيو انات إلى أربعة مجمو عات تخذت كل المجمو عات على على عليقة أساسية تتكون من 30 كجم برسيم ، 6 كجم مركزات ، 6 كلئ 6

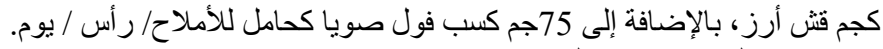

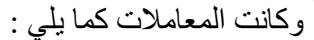

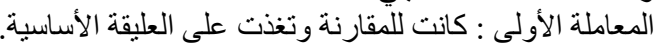

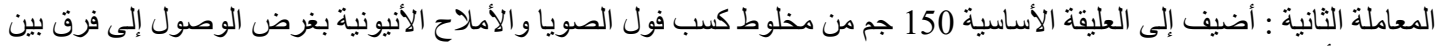

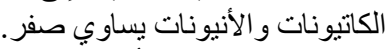

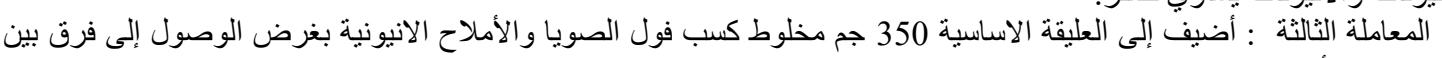

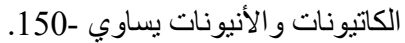
المعاملة الرابعة : أضيف إلى العليقة الاساسية 350 جم من مركبالانيونوريل بغرض الوصول إلى فرق بين الكاتيونات والأنيونات

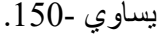
استمرت المعاملات لمدة ثلاثة أسابيع قبل الموعد المتوقع للو لادة وتوقفت يوم الولادة بينما استمر أخذ العينات والقرءات حتى نهاية

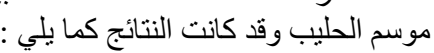

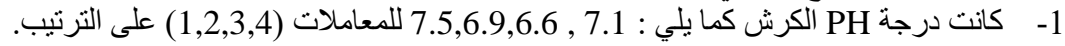

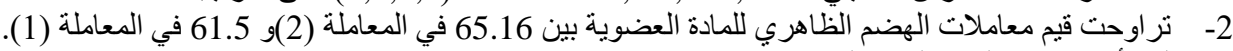

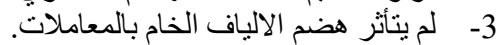

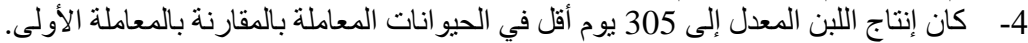

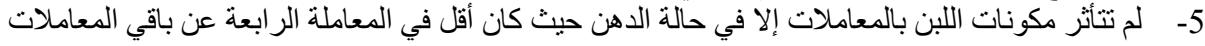

